\title{
Nutlet micromorphology of Indian Leucas (Lamioideae: Lamiaceae) with emphasis on its systematic implication
}

\author{
Mannethody Sajna and P. Sunojkumar* \\ Department of Botany, University of Calicut, Calicut University P.O., Malappuram, Kerala - 673 635, India \\ *E-mail: drsunoj@gmail.com
}

\begin{abstract}
Nutlet micromorphological characteristics in 40 taxa of Asian Leucas and two related species of African Leucas found in India were examined by light and scanning electron microscopy. Six types of basic ornamentation patterns can be distinguished: scalariform, verrucate, reticulate, ruminate, colliculate, and rugose. Of these, scalariform type was the most common and was found in all the sections of Asian Leucas, but the variation in alignment, size and shape of its composing cells provide further evidence in distinguishing the taxa. Verrucate, the second most frequent type was found in six species while other types were represented by only one to three species. However, the presence of colliculate sculpturing is more useful for separating African species from Asian Leucas. In Asian Leucas, nutlet size may be an important character rather than ornamentation for sectional division. Again, the type of glandular hairs on the nutlet apex can be used as a distinctive taxonomic character at specific level to separate L. martinicensis (Jacq.) R.Br. and L. urticifolia (Vahl) Sm. The results revealed high similarity of these taxa to the sect. Leucas. This study supports earlier observations on pericarp structure and subsequent phylogenetic analysis but is not in corroboration with the recent classification of Indian Leucas.
\end{abstract}

Keywords: Asian Leucas, India, micromorphology, nutlet

\section{Introduction}

Leucas R.Br. comprises about 100 species distributed mainly on dry or disturbed ground in tropical to southern Africa, Arabia, tropical and subtropical parts of Asia and Australia (Harley et al., 2004). Highest number of taxa is reported in the northeast tropical Africa (Ryding, 1998), and in India (Singh, 2001). Species prefers low $( \pm 800$ $\mathrm{m})$ to high $(800-2600 \mathrm{~m})$ altitudes and grows in ecologically divergent localities such as sea coasts, paddy fields, near wet lands, road sides, open habitats, farm land, plantations, grasslands, rocky hills, scrub jungles and shola grasslands.

Surface micromorphology of nutlets have become one of the strongest evidence reported to be useful at various taxonomic levels in Lamiaceae and related families, such as Verbenaceae and Scrophulariaceae (Wojciechowska, 1966; Sivarajan, 1981; Husain et al., 1990; Budantsev \& Lobova, 1997; Jamzad et al., 2000; Attar et al., 2007; Krawczyk \& Glowacka, 2015). In addition to surface sculpturing, pericarp structure, types of exocarp cells and indumentum features were also considered to be taxonomically important (Barthlott, 1981; Demissew \& Harley, 1992; Ryding, 1993, 1995; Oran, 1996; Guerin, 2005; Moon \& Hong, 2006; Kahraman et al., 2011). In some genera of Lamiaceae, nutlet characters were potentially useful in infrageneric classification (Demissew \& Harley, 1992) as well as at specific and subspecific levels (Marin et al., 1994; Navarro \& El Oualidi, 2000; Sampath Kumar \& Murthy, 2012; Satıl et al., 2012; Krawczyk \& Glowacka, 2015). In Stachys L., one of the largest genera of Lamiaceae, it has been shown that the sculpturing pattern of nutlet surface is more useful to separate species within sections, rather than characterizing large natural groups as sections (Salmaki et al., 2008). Studies on Salvia L. showed that gross morphology of nutlets and their sculpturing pattern are variable and taxonomically useful for species delimitation (Oran, 1996; Kahraman et al., 2011). The importance of nutlet morphological characteristics shown here has proven to be of great use in species discrimination and studying taxonomic relationships. 


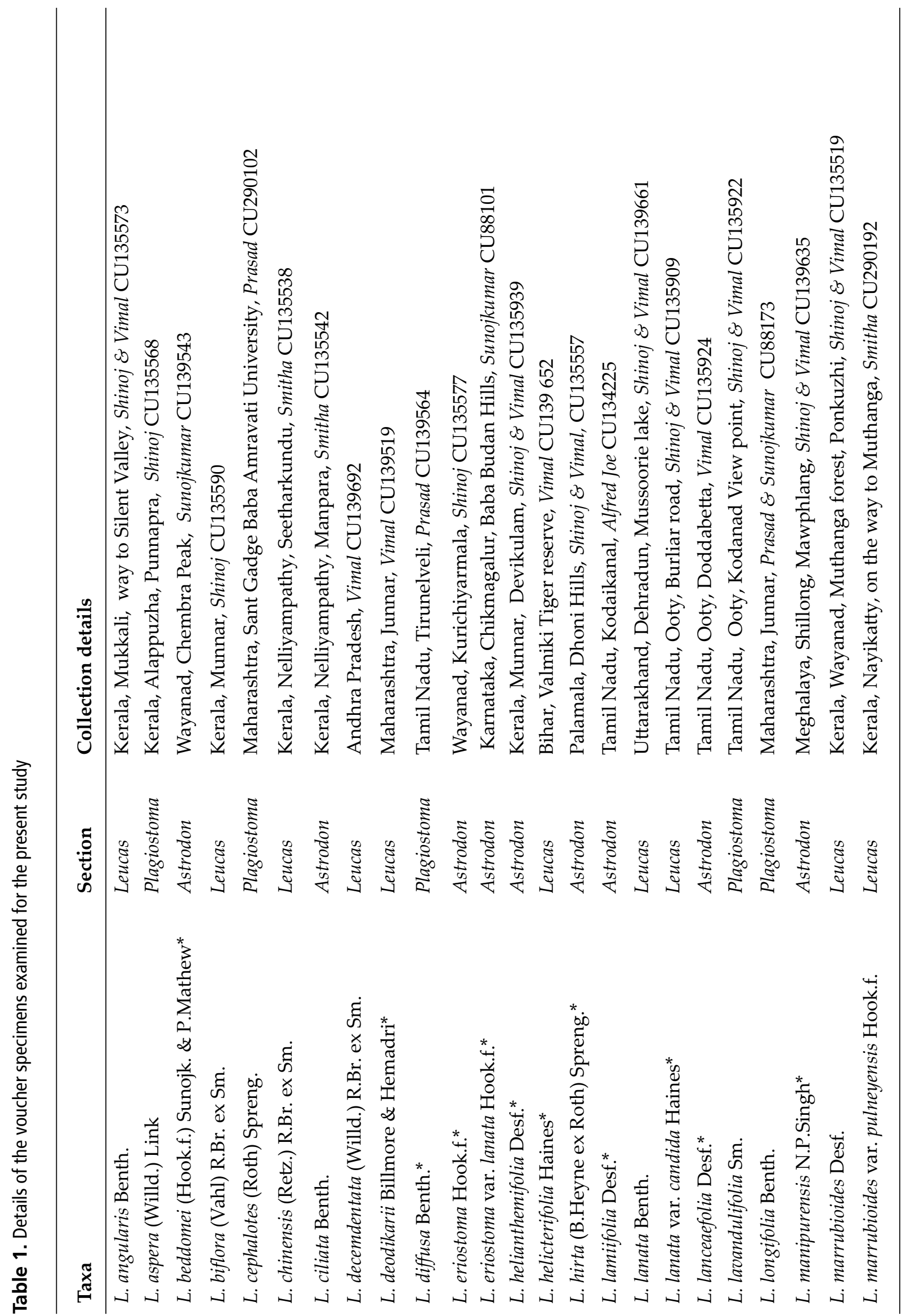




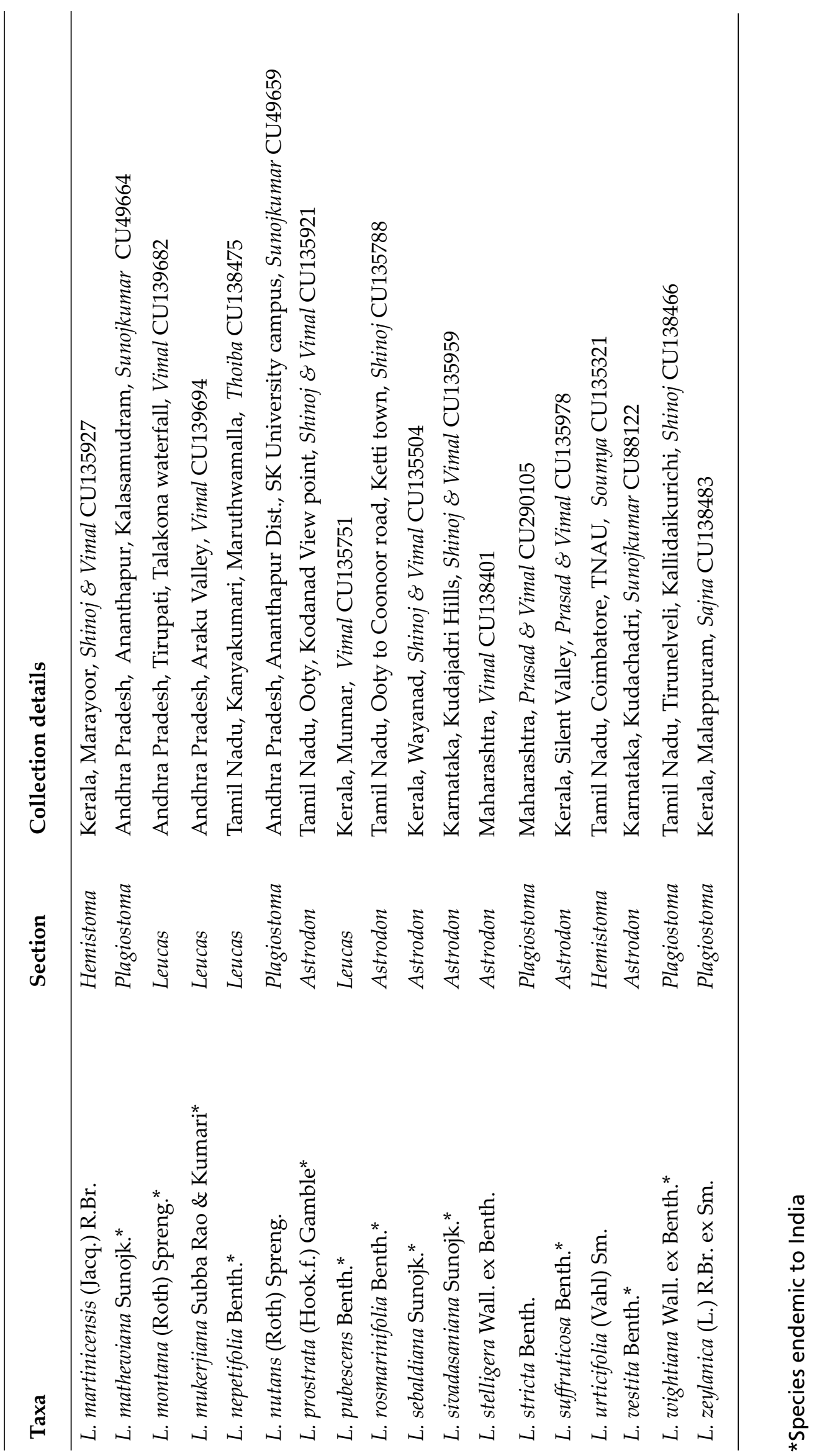


Based on Wallich's collections from Asian countries, Bentham (1832-1836, 1848) recognized six sections in Leucas. Recently, Scheen and Albert (2007) suggested segregation of this genus into two different groups, Leucas s.s. and 'African Leucas' based on their molecular phylogenetic studies (Scheen \& Albert, 2009). Leucas s.s. is monophyletic whereas 'African Leucas' is an informal name given to the paraphyletic group comprising African Leucas species and related genera such as Isoleucas, Leonotis, Otostegia and Acrotome. Morphologically abrupt demarcation between Asian and African species was earlier suggested by Sebald (1980) and Ryding (1998). Both of these groups are apparently related, and resembling each other mainly in the absence of branched trichomes, and presence of a beard along the margin of upper lip of corolla (Hedge, 1992).

According to Bentham's classification (18321836, 1848), Asian Leucas consists of three natural sections: sect. Astrodon Benth., sect. Plagiostoma Benth., and sect. Leucas (Ortholeucas) Benth. In the morphology based revision of Indian Leucas, Singh (2001) added three new sections (sect. Stricta, sect. Hyssopifolia, and sect. Diffusa) to Bentham's classification and treated Leucas found in India under six infrageneric groups. Besides c. 41 Asian species, two African species, L. martinicensis and L. urticifolia, originally included in African Leucas sect. Hemistoma Benth. are also found as introduced weeds in India. In the revision on Indian Leucas, Singh (2001) treated these two African species in separate sections, keeping L. urticifolia in the sect. Hemistoma and L. martinicensis under sect. Plagiostoma intermixed with other species of Leucas s.s. Here we made an attempt to utilize nutlet micro morphological data in the systematic treatment of genus Leucas s.s. based on specimens gathered from India.

Majority of Asian Leucas are found in India and a few works are available on the taxonomy of this genus (Metcalf \& Chalk, 1950; Abu-Asab \& Cantino, 1987; Cantino, 1990; Ryding, 1993, 1995, 1998; Singh, 2001; Scheen \& Albert, 2007, 2009; Sunojkumar \& Mathew, 2008). However, there is no report yet addressing the significance of nutlet micromorphology in the sytematics of Asian Leucas.

The present study attempts to investigate nutlet surface features of Asian Leucas found in India in a taxonomic context for the first time. In this study the authors used 60 accessions of 40 taxa of Asian Leucas and two species of African Leucas collected from India.

\section{Materials and Methods}

The details on specimens analyzed, collection data and the vouchers used are provided in Table 1. Nutlets werecollected fromnatural populations and the herbarium specimens deposited in the Calicut University Herbarium (CALI). Initially, nutlets were observed using Leica M80 stereomicroscope to check that they are of normal size and maturity. The dorsal surface of nutlet was considered for describing surface sculpturing, to ensure certainty about the stability of characters among different accessions of one species. The measurements were made on 20 nutlets per species randomly obtained from five to eight populations of each species. The ranges of nutlet measurements were presented in box plot graphics generated in $\mathrm{R}$.

For scanning electron microscopy (SEM), dried mature nutlets were mounted directly on stubs using double-side adhesive tape, and sputter-coated with gold. Some micrographs were taken with a JEOL Model JSM-6390LV scanning electron microscope at $15 \mathrm{kV}$ and others were taken with a Hitachi SU 6600 Horiba-Emax EDS scanning electron microscope at $10 \mathrm{kV}$.

Even though the terminology of Barthlott (1981) has been used in describing surface sculpturing in several species of seed plants, the authors found those of Stearn (1992) and Salmaki et al. (2008) to be more applicable to the patterns in Leucas.

\section{Results}

The nutlet characters of all investigated taxa are listed in Table 2. Selected SEM micrographs of nutlets studied are illustrated in Figures 1-2. Among several characters of nutlets studied, the type of sculpturing, shape of anticlinal and periclinal walls, shape and size of nutlets and presence or absence of glandular and non glandular hairs were considered to be taxonomically most important. Nutlets show considerable variability among species in different sections, and therefore, afford valuable characters in delimitation of sections and species.

Nutlets have slightly elongate trigonous structure with two comparatively flat or sometimes even concave proximal sides and a broader, more rounded distal side. Nutlets in most of the studied species of Leucas are (Table 2) narrow oblong (Fig. 1i; Fig. 2b), oblong (Fig. 2k) to broad oblong (Fig. 2d), obovate (Fig. 2e) to broad obovate (Fig. 1i) and triquetrous in cross section. The apex is rounded (Fig. 2e) or truncate (Fig. 1i) and colour varies from blackish to light brownish. 

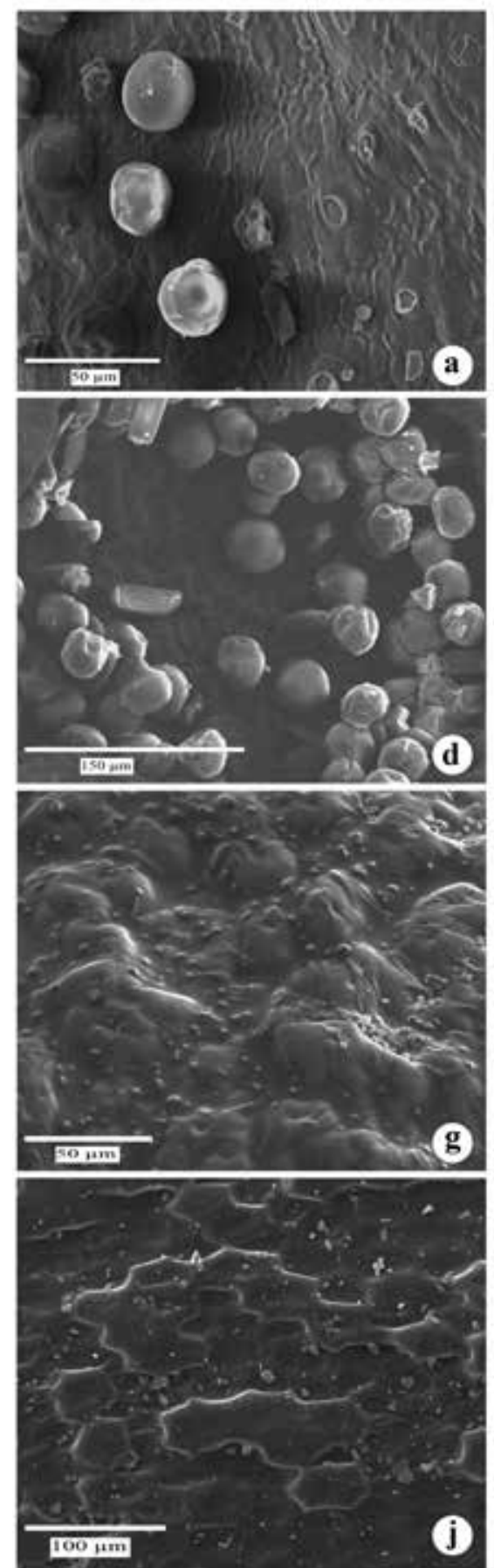
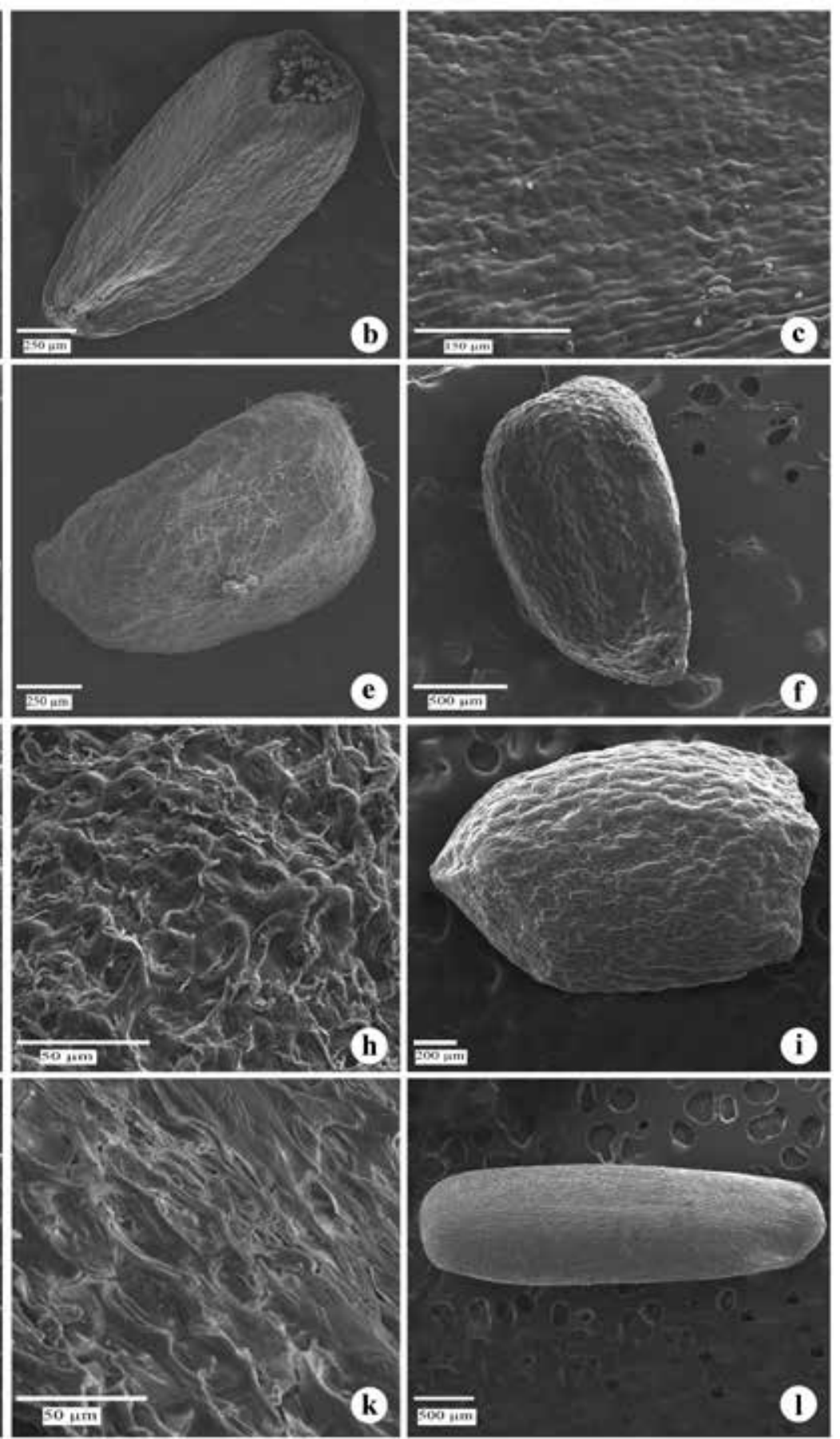

Fig. 1. SEM micrographs of nutlets in some taxa of Leucas: a. L. martinicensis; b, c \& d. L. urticifolia; e. L. angularis; f \& g. L. biflora; h. L. chinensis; i \& j. L. lanata; k. L. aspera; I. L. cephalotes.

Nutlet length ranges from $1.37 \mathrm{~mm}$ (L. angularis) to $4.27 \mathrm{~mm}$ (L. mathewiana) and $0.79 \mathrm{~mm}$ (L. nutans) to $1.85 \mathrm{~mm}$ (L.suffruticosa) in width (Table 2).

The Asian Leucas usually do not possess hairs on nutlets, which is a common character seen in African Leucas including the two African species found in India: L. martinicensis and L. urticifolia. However, glandular hairs seen on L. beddomei and non-glandular hairs on L. angularis (Fig. 1e) as exceptions in Asian taxa. The hairs are subsessile in L. beddomei (Fig. 2g) and L. martinicensis (Fig. 1a) where as it is stalked in L. urticifolia (Fig. 1d).

Nutlet surface sculpturing pattern can broadly be classified in six types (Table 2): The most common is the scalariform type as in L. beddomei (Fig. 2f), $L$. aspera (Fig. 1k) and L. lavandulifolia (Fig. 2a). The 


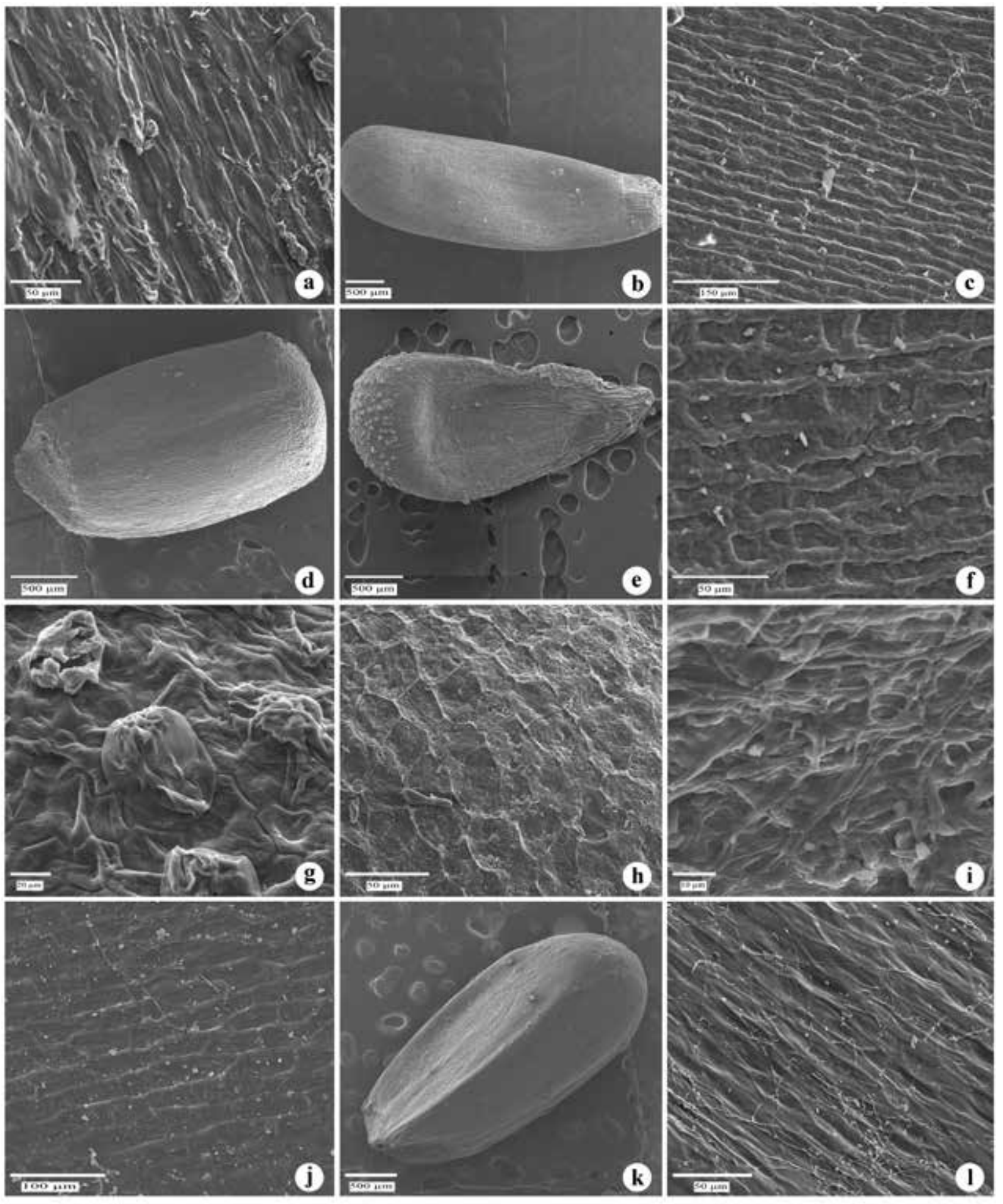

Fig. 2. SEM micrographs of nutlets in some taxa of Leucas: a. L. lavandulifolia; b \& c. L. mathewiana; d. L. stricta; e, f \& g. L. beddomei; h. L. hirta; i. L. lanceaefolia; j. L. sebaldiana; k \& I. L. stelligera.

other types are colliculate as in L. urticifolia (Fig. 1c); reticulate as in L. hirta (Fig. 2h); verrucate as in L. biflora (Fig. 1g) and L. lanata (Fig. 1j); rugose as in L. chinensis (Fig. $1 \mathrm{~h}$ ); and ruminate as in $L$. lanceaefolia (Fig. 2i). The scalariform pattern was found in 27 species out of 42 species studied, followed by verrucate ( 6 species), reticulate and ruminate pattern (each with 3 species), colliculate ( 2 species), and rugose (1 species).

In scalariform type, the species vary according to the alignment, size and shape of its composing cells, may be short celled as in L. aspera (Fig. 1k) and L. beddomei (Fig. 2f) or long celled as in $L$. lavandulifoia (Fig. 2a) and L. mathewiana (Fig. 2c). 
Nutlets in studied species of African Leucas show relationship with the members of sect. Leucas. They are obovate in shape, $\pm 1.97 \times 1.17 \mathrm{~mm}$ ( $L$. martinicensis) and $\pm 1.76 \times 0.91 \mathrm{~mm}$ (L. urticifolia) in size and show colliculate (Fig. 1c) type of sculpturing.

\section{Discussion}

The results of present work show the utility of nutlet micromorphological characters for distinguishing species in Leucas. These kinds of characters have shown to be diagnostic and of systematic value as in previous studies of nutlet morphology in Lamiaceae (Husain et al., 1990; Moon \& Hong, 2006; Sampath Kumar \& Murthy, 2012; Krawczyk \& Glowacka, 2015). However, Navarro and El Oualidi (2000) found that the presence or absence of different type of glandular trichomes on the nutlet surface is the most important character in Teucrium L. whereas in tribe Saturejeae, nutlet shape and the nature of attachment scar are the significant characters in delimitation of taxa (Husain et al., 1990).

Among different nutlet characters studied, the type of sculpturing has been considered to be taxonomically most valuable ones (Oran, 1996). The scalariform type is the most common type among the examined taxa, but the variations in alignment, size and shape of its composing cells provide further support for using nutlet morphology to distinguish species. For instance, in sect. Plagiostoma, L. aspera is morphologically similar to its close allies such as L. lavandulifolia, L. stricta, L. wightiana and L. zeylanica, all showing scalariform type of sculpturing, are characterized by concave periclinal and non-wavy raised anticlinal walls. But can easily be distinguishable by the pericarp cells of $L$. aspera being short (Fig. $1 \mathrm{k}$ ). The pericarp cells of L. lavandulifolia (Fig. 2a), L. stricta, L. wightiana and L. zeylanica is long.

However, the type of sculpturing is more useful in the separation of Asian Leucas from African species. In terms of macromorphology, the former is characterized by having 8-10-toothed calyx with ciliate hairs at the mouth and different forms of habit such as annual and perennial herbs as well as sub shrubs and shrubs, while African Leucas are annuals with 5-10-toothed calyx without cilia at the mouth. Presence of colliculate sculpturing and glandular trichomes at nutlet apex has high systematic value for the segregation of this genus into Leucas s.s. and African Leucas. Moreover, Ryding (1993) pointed out that a combination of three morphological characters, absence of glands on ovaries and nutlets, anterior corolla lip longer than posterior corolla lip, and dorsal side of calyx exceeding or equaling the ventral sides distinguish Asian species from the African species of Leucas. Even though they do not form a combination of three states in all taxa of African Leucas, but are similar in one of these characters (Ryding, 1998). So, these kinds of nutlet morphological characters are consistent with the macromorphological classification (Bentham, 1832-1836, 1848) and provide additional evidence to verify the segregation in Leucas.

As given in other Lamiacean genera (Salmaki et al., 2008; Özkan et al., 2009; Tarimcilar et al., 2013; Sampath Kumar \& Murthy, 2012; Kaya et al., 2015), nutlet size also have valuable taxonomic significance in different sections of Asian Leucas. Based on nutlet length, sections of Asian Leucas are clearly separated (Fig. 3): sect. Leucas is characterized by very small nutlets $(<2 \mathrm{~mm})$, sect. Astrodon with very large nutlets $(>2.5 \mathrm{~mm})$ whereas sect. Plagiostoma possess intermediate length $(2-2.5 \mathrm{~mm})$. The occurrence of these three kinds of nutlets is also in accordance with leaf morphology in the three sections of Asian Leucas: sect. Leucas have ovate leaves, sect. Astrodon have oblong or linear-oblong leaves and sect. Plagiostoma is characterized by linear-lanceolate leaves.

Oran (1996) suggested that the shape of nutlets has low systematic importance in evaluating relationship among species. However, from a taxonomical perspective, the shape of nutlets can be used in separation of taxa in certain instances. For example, in sect. Ortholeucas, L. pubescens and L. lanata (Fig. 1i) with broad obovate nutlets are easily distinguishable from other species of this section. Similarly, L. aspera, L. cephalotes, L. nutans, L. diffusa and L. mathewiana in the sect. Plagiostoma are characterized by narrow oblong nutlets.

In Leucas, it has been suggested that the Asian species can be divided in to three natural groups based on pericarp structure (Ryding, 1993). The results obtained from the present study correlate with these features and are discussed below in a comparative context.

\section{Leucas sect. Astrodon Benth.}

Leucas sect. Astrodon Benth. is one of the largest section of Asian Leucas and represents the most taxonomically diverse group of plants. Singh (2001) divided this section into three separate sections: Astrodon, Diffusa and Hyssopifolia, based 


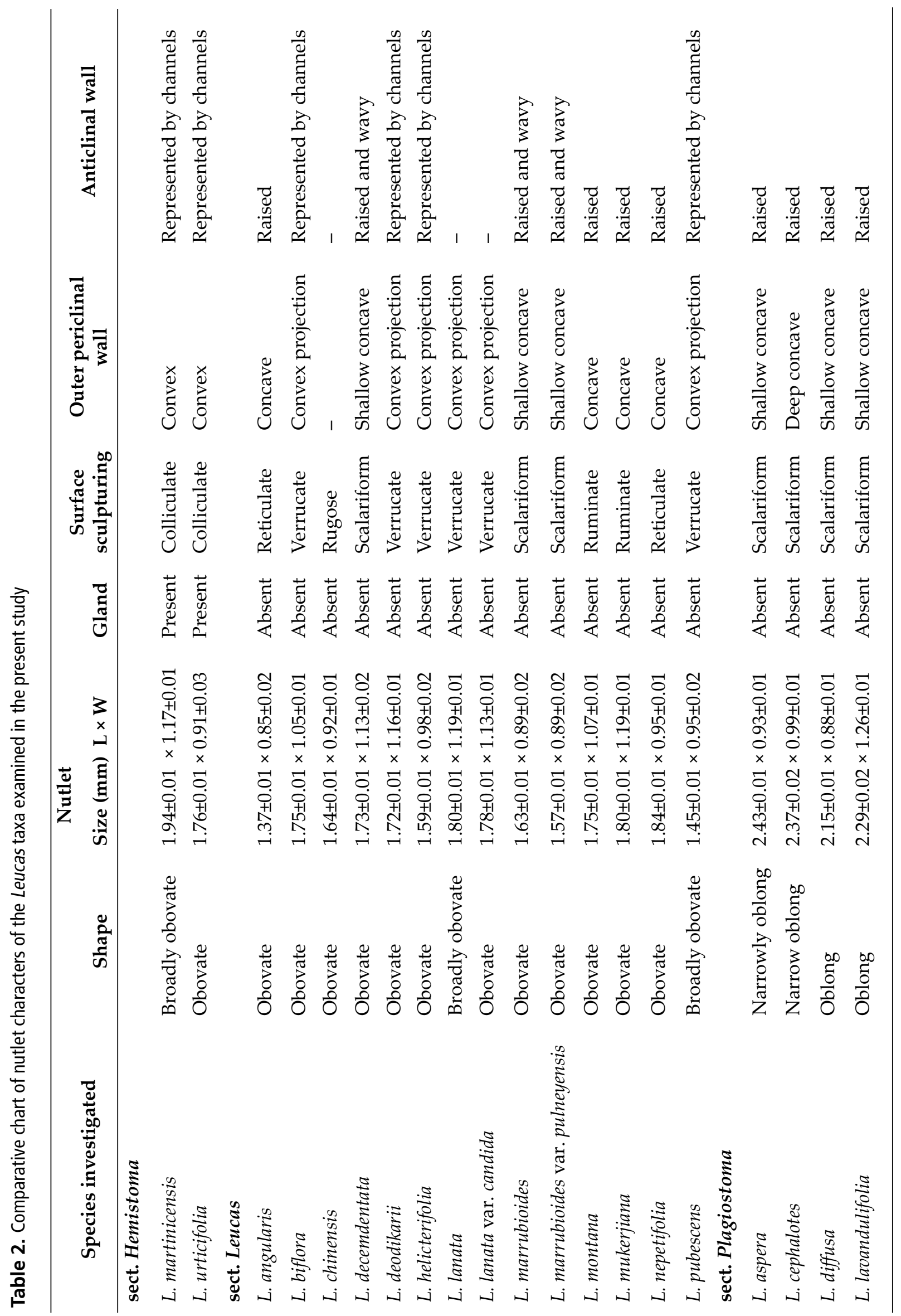




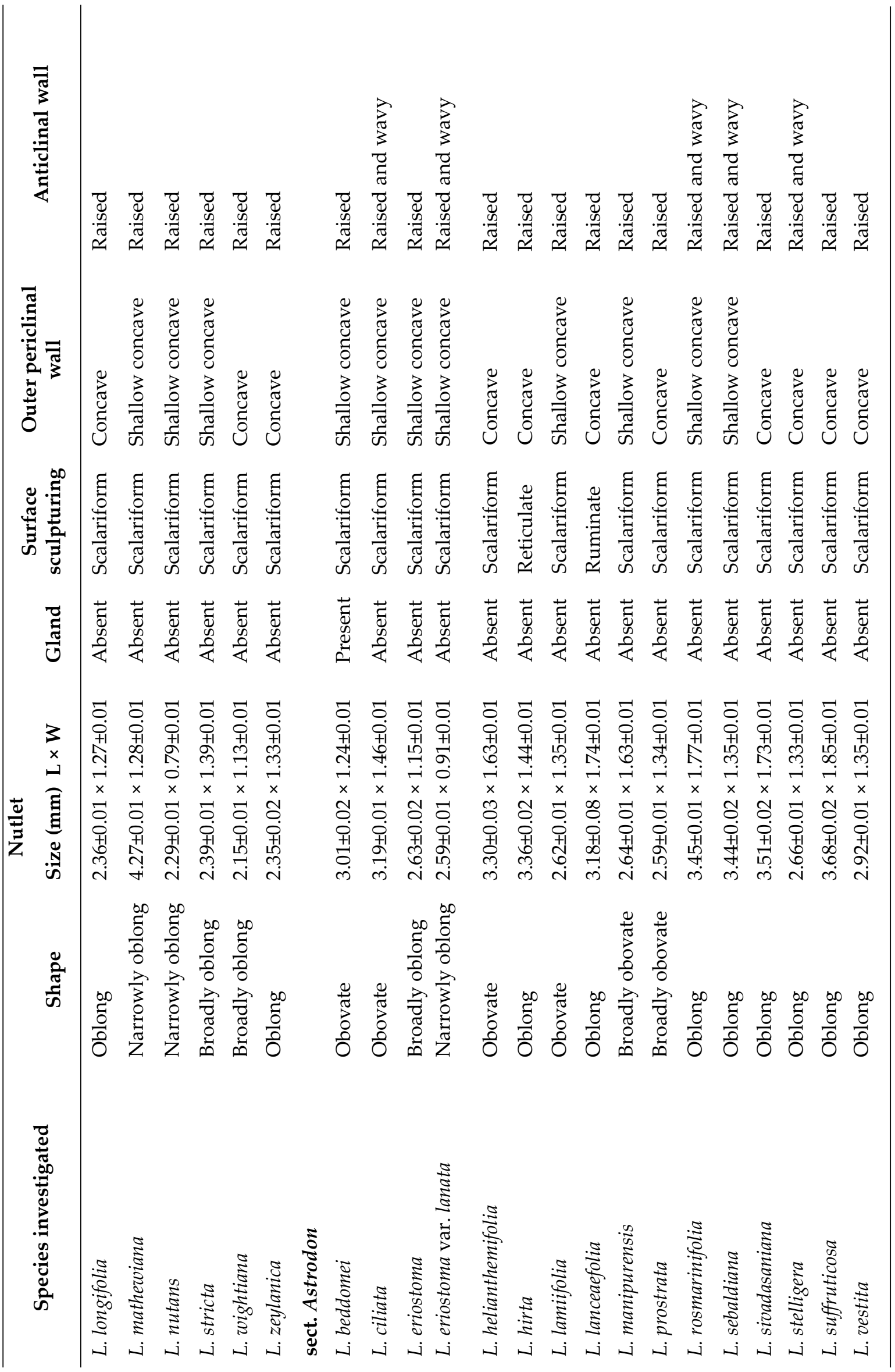




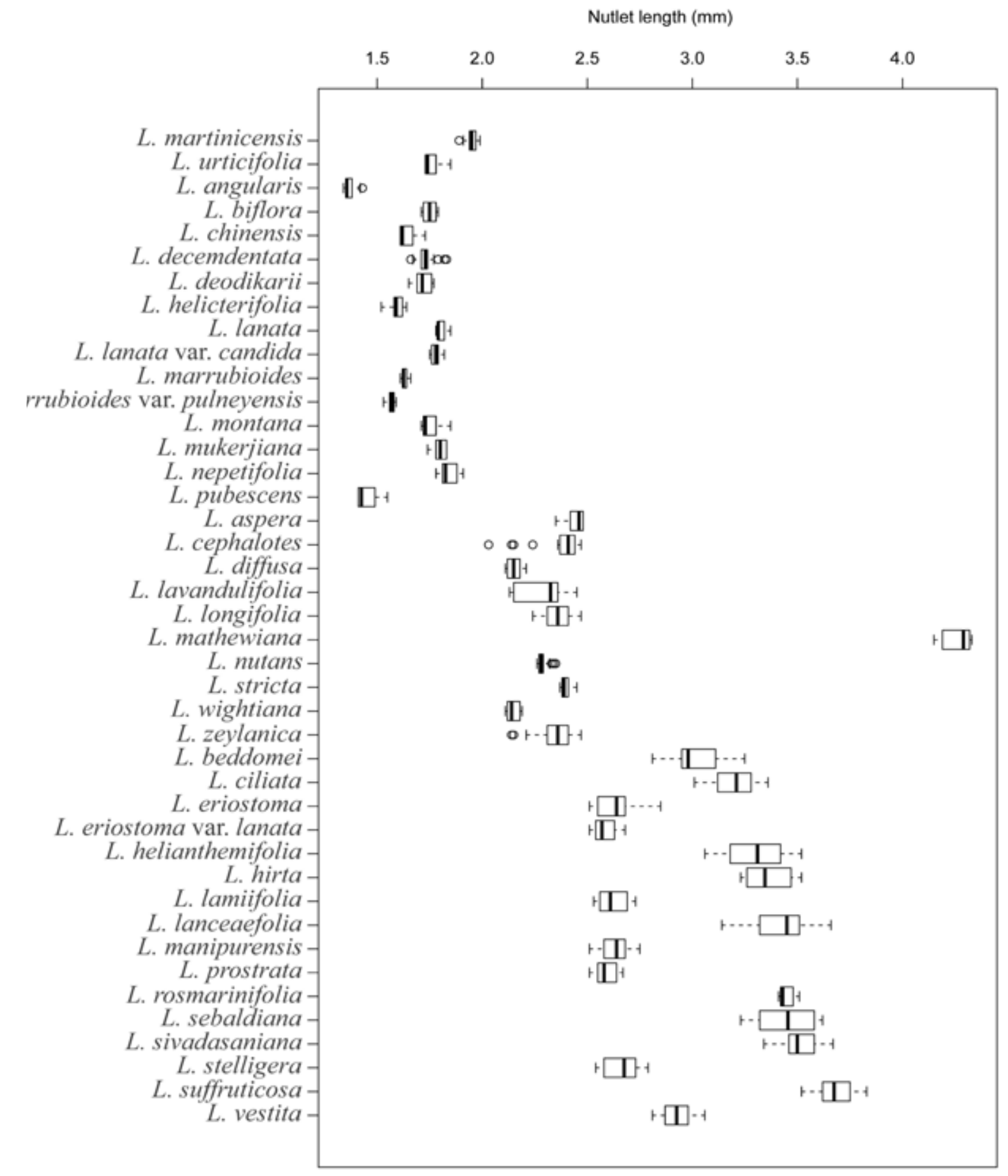

Fig. 3. Box plot graphic for nutlet length in the studied species of Leucas.

on certain morphological characters he observed in certain herbarium specimens. Our observation of both live and herborized specimens confirms that Leucas sect. Astrodon (Bentham, 1832-1836, 1848 ) is characterized by having straight tubular to campanulate calyces, which are densely ciliate with dense shining hairs at mouth. Besides these features, all species attributed to this section possess long non-glandular trichomes and lack capitate trichomes. Moreover, presence of many veins in the nutlets (veins over five and displaced from nutlet edges) and very high bone cells (Ryding, 1993) can be used as distinctive characters of this section. Among the species of this section, $L$. beddomei possess subsessile glands on nutlet apex (Sunojkumar \& Mathew, 2008). Morphologically, 
this species is closely similar to L. hirta (subshrubs with elliptic leaf blades and many flowered verticils). But the latter can be distinguished by the presence of its unique reticulate sculpturing. The Western Ghats endemic species L. lanceaefolia is unique in this section due to the presence of ruminate type of sculpturing with concave periclinal and raised anticlinal walls.

\section{Leucas sect. Plagiostoma Benth.}

Most of the species in this section are medicinal herbs, widely distributed in Asian countries like Bangladesh, China, India, Malaysia, Myanmar, Philippines and Sri Lanka and exhibit their presence even up to Australian continent. This section is characterised by linear-lanceolate leaves, terminal compact verticils, oblique calyx and fan-shaped lower lip of corolla. Singh (2001) treated members of this section in three separate sections: Diffusa, Plagiostoma and Stricta. From nutlet micromorphological point of view, it is not possible to find any significant differences between the sections as mentioned above indicating the possible close relationship between them. According to Ryding (1993) presence of a more or less distinct foot-like structure at the base of nutlets and elongate or unequally thickened exocarp cells are one of the most important characteristic feature used for separating this section which is observed in our studies also. However, the Eastern Ghats endemic species L. mathewiana of this section possess the largest nutlets in the genus.

\section{Leucas sect. Leucas Benth.}

This section is characterized by small obovate nutlets and shows close similarity with the African Leucas in India but can be distinguished based on the glandular hairs at nutlet apex. Species of this section possess both pitted and ordinary type of exocarp cells in pericarp (Ryding, 1993) and is characterized by the presence of different types of sculpturing patterns. Amongst the species of this section, L. angularis and L. pubescens are very closely related in morphological features such as ovate leaves, long bracteoles, lesser number of flowers, coriaceous, long and cylindrical calyx. But the two can be distinguished based on sculpturing type, which is verrucate with convex periclinal walls in L. pubescens whereas reticulate with concave periclinal walls in L. angularis. Nutlet characters of L. pubescens provided a conclusive evidence to consider this species under the section Leucas, contrary to what has been suggested by Singh (2001) who placed L. pubescens in sect. Hyssopifolia.
Non-glandular hairs are noticed throughout on the nutlets of $L$. angularis (Fig. 1e) and on both end of nutlets in L. mukerjiana (Singh, 2001) as taxa specific characters.

\section{'African Leucas' sect. Hemistoma Benth.}

This section includes two species in India, which are widely distributed in Asia and Africa. Both species possess glandular hairs at nutlet apex, which, however, are subsessile in L. martinicensis and stalked in L. urticifolia. Moreover, the pericarp thickness is lesser $(20-25 \mu \mathrm{m})$ in L. martinicensis, but thicker (about $55 \mu \mathrm{m}$ ) in L. urticifolia (Ryding, 1993). Therefore, the type of indumentum and pericarp thickness supports close relationships of these two species. Our study on L. martinicensis and L. urticifolia found in Asia supported Sebald's (1980) and Ryding's (1993) inclusion of these two species in sect. Hemistoma, which is contrary to what has been suggested by Singh (2001) to include L. martinicensis in sect. Plagiostoma.

\section{Conclusion}

Nutlet micromorphological observations provide strong support for the delimitation of African species from Asian Leucas. Among the characters studied, sculpturing pattern proved as useful character to separate African species from Asian Leucas. Within the Asian group, size of nutlets appears useful in separating species under three large natural groups as sections. However, the micromorphological data can be combined with a broad range of morphological characters in order to differentiate each taxa within the genus. Compared to other genera in Lamiaceae (Guerin, 2005) nutlet sculpturing in Leucas provides only low phylogenetic significance due to less variation among closely related species. Based on micromorphology, the Asian Leucas sect. Leucas shows possible relationships with African Leucas, providing a link between the two groups.

\section{Acknowledgements}

The authors thank forest departments of various states particularly Kerala forest department for granting permission to collect specimens from protected areas. The first author express thanks to University Grants Commission for Maulana Azad National Fellowship. The second author is grateful to Department of Biotechnology, Government of India (Grant No. BT/PR5423/BCE/8/907/2012) for providing financial support. 


\section{Literature Cited}

Abu-Asab, M.S. \& P.D. Cantino 1987. Phylogenetic implications of leaf anatomy in subtribe Melittidinae (Labiatae) and related taxa. J. Arnold Arbor. 68: 1-34.

Attar, F., Keshvari, A., Ghahreman, A., Zarre, S. \& F. Aghabeigi 2007. Micromorphological studies on Verbascum (Scrophulariaceae) in Iran with emphasis on seed surface, capsule ornamentation and trichomes. Flora 202: 169175.

Barthlott, W. 1981. Epidermal and seed surface characters of plants: systematic applicability and some evolutionary aspects. Nord. J. Bot. 1: 345-355.

Bentham, G. 1832-1836. Labiatarum genera et species. James Ridgway \& sons, London. pp. 602-618.

Bentham, G. 1848. Labiatae. In: de Candolle AP (Ed.) Prodromous systematis naturalis regni vegetabilis. Treuttelet \& Würtz, Paris. pp. 27-603.

Budantsev, A.L. \& T.A. Lobova 1997. Fruit morphology, anatomy and taxonomy of tribe Nepeteae (Labiatae). Edinburgh J. Bot. 54: 183216.

Cantino, P.D. 1990. The phylogenetic significance of stomata and trichomes in the Labiatae and Verbenaceae. J. Arnold Arbor. 71: 323-370.

Demissew, S. \& M.M. Harley 1992. Trichome, seed surface and pollen characters in Stachys, Lamioideae (Labiatae) in Tropical Africa. In: Harley, R.M. \& T. Reynolds (Eds.) Advances in Labiatae science. Royal Botanic Gardens, Kew. pp. 149-166.

Guerin, G.R. 2005. Nutlet morphology in Hemigenia R.Br. and Microcorys R.Br. (Lamiaceae). Pl. Syst. Evol. 254: 49-68.

Harley, R.M., Atkins, S., Budantsev, A.L., Cantino, P.D., Conn, B.J., Greyer, R., Harley, M.M., De Kok, R., Krestovskaja, T., Morales, R., Paton, A.J., Ryding, O. \& T. Upson 2004. Labiatae. In: Kubitzki, K. \& J.W. Kadereit (Eds.) The families and genera of vascular plants.Vol. 7. Springer, Berlin. pp. 167-275.

Hedge, I.C. 1992. A global survey of the biogeography of the Labiatae. In: Harley, R.M. \& T. Reynolds (Eds.) Advances in Labiatae science. Royal Botanic Gardens, Kew. pp. 7-17.
Husain, S.Z., Marin, P.D., Šilić, C., Qaiser, M. \& B. Petković 1990. A micromorphological study of some representative genera in the tribe Saturejeae (Lamiaceae). Bot. J. Linn. Soc. 103: 59-80.

Jamzad, Z., Harley, M.M., Ingrouille, M., Simmonds, M.S.J. \& A. Jalili 2000. Pollen exine and nulet surface morphology of the annual species of Nepeta L. (Lamiaceae) In Iran. In: Harley, R.M., Morton, C.M. \& S. Blackmore (Eds.) Pollen and Spores: Morphology and Biology. Kew. pp. 385-397.

Kahraman, A., Celep, F., Doğan, M., Guerin, G.R. \& S. Bagherpour 2011. Mericarp morphology and its systematic implications for the genus Salvia L. section Hymenosphace Benth. (Lamiaceae) in Turkey. Pl. Syst. Evol. 292: 3339.

Kaya, A. \& T. Dirmenci 2008. Nutlet surface micromorphology of the genus Nepeta L. (Lamiaceae) in Turkey. Turk. J. Bot. 32: 103112.

Krawczyk, K. \& K. Glowacka 2015. Nutlet micromorphology and its taxonomic utility in Lamium L. (Lamiaceae). Pl. Syst. Evol. 301: 1863-1874.

Marin, P.D., Petković, B.P. \& S. Duletić 1994. Nutlet sculpturing of selected Teucrium species (Lamiaceae): a character of taxonomic significance. Pl. Syst. Evol. 192: 199-214.

Metcalf, C.R. \& L. Chalk 1950. Anatomy of the Dicotyledons, Vol. 2. Oxford Press, London.

Moon, H.K. \& S.P. Hong 2006. Nutlet morphology and anatomy of the genus Lycopus (Lamiaceae: Menthae). J. Plant Res. 119: 633-644.

Navarro, T. \& J. El Oualidi 2000. Trichome morphology in Tucrium L. (Labiatae). A taxonomic review. Anales Jard. Bot. Madrid 57: 277-297.

Oran, S.A. 1996. Ultrastructure of nutlet surface of the genus Salvia L. in Jordan and the neighbouring countries. Dirasat Nat. Engin. Sci. 23: 393-408.

Özkan, M., Aktas, K., Özdemir, C. \& G. Guerin 2009. Nutlet morphology and its taxonomic utility in Salvia (Lamiaceae: Mentheae) from Turkey. Acta Bot. Croat. 68: 105-115.

Ryding, O. 1993. Pericarp structure of Leucas and related genera (Lamiaceae subfam. Lamioideae). Nord. J. Bot. 13: 637-646. 
Ryding, O. 1995. Pericarp structure and phylogeny of the Lamiaceae-Verbenaceae-complex. Pl. Syst. Evol. 198: 101-141.

Ryding, O. 1998. Phylogeny of the Leucas group (Lamiaceae). Syst. Bot. 23: 235-247.

Salmaki, Y., Zarre, S., \& Z. Jamzad 2008. Nutlet micromorphology and its systematic implications in Stachys L. (Lamiceae) in Iran. Feddes Repert. 119: 607-621.

Sampath Kumar, V. \& G.V.S. Murthy 2012. SEM studies on the Nutlets of Certain Genera in the Tribe Mentheae (Labiatae) in Indian Region. In: V. S. Ramachandran (Ed.) Plant Diversity and Conservation. Pointer Publishers, Jaipur. pp. 193-214.

Satıl, F., Kaya, A., Akçiçek, E. \& T. Dirmenci 2012. Nutlet micromorphology of Turkish Stachys sect. Eriostomum (Lamiaceae) and its systematic implications. Nord. J. Bot. 30: 352364.

Scheen, A.C. \& V.A. Albert 2007. Nomenclatural and taxonomic changes within the Leucas clade (Lamioideae; Lamiaceae). Syst. Geogr. Plants 77: 229-238.

Scheen, A.C. \& V.A. Albert 2009. Molecular phylogenetics of the Leucas group (Lamioideae; Lamiaceae). Syst. Bot. 34: 173-181.

Sebald, O. 1980. Die Gattung Leucas R. Brown (Labiatae) in Afrika und auf der Arabischen Halbinsel. Stuttgarter Beitr. Naturk. 341: 1-200.
Singh, V. 2001. Monograph on Indian Leucas R. Br. (Dronapushpi) Lamiaceae. Scientific Publishers, Jodhpur.

Sivarajan, V.V. 1981. Scanning electron microscopic studies on the seed-coat surface patterns of South Indian species of Lindernia All. (Scrophulariaceae). Proc. Indian Acad. Sci. 90: 499-508.

Stearn, W.T. 1992. Botanical Latin. David and Charles Publishers,USA.

Sunojkumar, P. \& P. Mathew 2008. South Indian Leucas: A Taxonomic Monograph. CRIKSC Publishers, Calicut.

Tarimcilar, G., Yilmaz, Ö., Daşkini, R. \& G. Kaynak 2013. Nutlet morphology and its taxonomic significance in the genus Mentha $\mathrm{L}$. (Lamiaceae) from Turkey. Bangladesh J. Plant Taxon. 20: 9-18.

Wojciechowska, B. 1966. Morphology and anatomy of fruits and seeds in the family Labiatae with particular respects to medicinal species. Monogr. Botan. 21: 1-244.

Received: 30.09.2017

Revised and Accepted: 06.04.2018 